ISSN 2072-6651

www.mdpi.com/journal/toxins

Article

\title{
Triggering of Suicidal Erythrocyte Death by Celecoxib
}

\section{Adrian Lupescu, Rosi Bissinger, Kashif Jilani and Florian Lang *}

Department of Physiology, University of Tuebingen, Gmelinstraße 5, Tuebingen 72076, Germany; E-Mails: lupescuadrian@gmx.de (A.L.); ro.bissinger@gmx.de (R.B.); kashif_cbc@yahoo.com (K.J.)

* Author to whom correspondence should be addressed; E-Mail: florian.lang@uni-tuebingen.de; Tel.: +49-7071-29-72194; Fax: +49-7071-29-5618.

Received: 19 August 2013; in revised form: 3 September 2013 / Accepted: 4 September 2013 / Published: 10 September 2013

\begin{abstract}
The selective cyclooxygenase-2 (COX-2) inhibitor celecoxib triggers apoptosis of tumor cells and is thus effective against malignancy. The substance is at least partially effective through mitochondrial depolarization. Even though lacking mitochondria, erythrocytes may enter apoptosis-like suicidal death or eryptosis, which is characterized by cell shrinkage and by phosphatidylserine translocation to the erythrocyte surface. Eryptosis may be triggered by increase of cytosolic $\mathrm{Ca}^{2+}$-activity $\left(\left[\mathrm{Ca}^{2+}\right]_{i}\right)$. The present study explored whether celecoxib stimulates eryptosis. Forward scatter was determined to estimate cell volume, annexin $\mathrm{V}$ binding to identify phosphatidylserine-exposing erythrocytes, hemoglobin release to depict hemolysis, and Fluo3-fluorescence to quantify $\left[\mathrm{Ca}^{2+}\right]_{i}$. A $48 \mathrm{~h}$ exposure of human erythrocytes to celecoxib was followed by significant increase of $\left[\mathrm{Ca}^{2+}\right]_{\mathrm{i}}(15 \mu \mathrm{M})$, significant decrease of forward scatter $(15 \mu \mathrm{M})$ and significant increase of annexin-V-binding $(10 \mu \mathrm{M})$. Celecoxib $(15 \mu \mathrm{M})$ induced annexin-V-binding was blunted but not abrogated by removal of extracellular $\mathrm{Ca}^{2+}$. In conclusion, celecoxib stimulates suicidal erythrocyte death or eryptosis, an effect partially due to stimulation of $\mathrm{Ca}^{2+}$ entry.
\end{abstract}

Keywords: cell membrane scrambling; phosphatidylserine; calcium; cell volume; eryptosis

\section{Introduction}

The anti-inflammatory selective cyclooxygenase-2 (COX-2) inhibitor celecoxib [1,2] triggers apoptosis [1-4] and is thus considered for the treatment of malignancy [1,4,5]. The proapoptotic 
activity of the drug is apparently not the result of COX-2 inhibition $[1,3]$ but at least partially due to decreased expression of Bcl-2 family members [4] and decreased mitochondrial potential [1,4]. Celecoxib further counteracts the anti-apoptotic proteins Mcl-1 and survivin [1]. Moreover, the drug has been shown to increase cytosolic $\mathrm{Ca}^{2+}$ activity $\left(\left[\mathrm{Ca}^{2+}\right]_{\mathrm{i}}\right)[6]$. The use of the drug is limited by its cardiovascular toxicity [1].

Cells like erythrocytes lacking mitochondria and nuclei should be insensitive to suicidal death triggered by mitochondrial depolarization and cytochrome c release [7]. Erythrocytes may, however, enter apoptosis-like suicidal death or eryptosis, which is characterized by cell shrinkage and phosphatidylserine scrambling of the cell membrane [7]. Eryptosis may be triggered by increase of $\left[\mathrm{Ca}^{2+}\right]_{\mathrm{i}}$. $\mathrm{Ca}^{2+}$ entry may be elicited by activation of $\mathrm{Ca}^{2+}$-permeable cation channels $[8,9]$. Stimulators of those channels include oxidative stress [10]. Increased $\left[\mathrm{Ca}^{2+}\right]_{\mathrm{i}}$ is followed by activation of $\mathrm{Ca}^{2+}$-sensitive $\mathrm{K}^{+}$channels [11] causing cell shrinkage due to $\mathrm{K}^{+}$exit, hyperpolarization, $\mathrm{Cl}^{-}$exit and thus cellular $\mathrm{KCl}$ and water loss [12]. Increased $\left[\mathrm{Ca}^{2+}\right]_{\mathrm{i}}$ further stimulates cell membrane scrambling with phosphatidylserine exposure at the erythrocyte surface [13]. The $\mathrm{Ca}^{2+}$ sensitivity of cell membrane scrambling is enhanced by ceramide [14]. Eryptosis is further stimulated by energy depletion [15], caspase activation [16-20], and deranged activity of distinct kinases, such as AMP activated kinase AMPK [9], cGMP-dependent protein kinase [21], Janus-activated kinase JAK3 [22], casein kinase [23,24], p38 kinase [25], as well as sorafenib [26] and sunifinib [27] sensitive kinases.

Eryptosis is stimulated by a myriad of xenobiotics [28-51] and observed in several clinical disorders [7], such as diabetes [20,52,53], renal insufficiency [54], hemolytic uremic syndrome [55], sepsis [56], sickle cell disease [57], malaria [58-62], Wilson's disease [62], iron deficiency [63], phosphate depletion [64], and presumably metabolic syndrome [51].

The present study explored the effect of celecoxib on $\left[\mathrm{Ca}^{2+}\right]_{\mathrm{i}}$, cell volume and phosphatidylserine abundance at the erythrocyte surface. As a result, the experiments disclose a powerful stimulating effect of celecoxib on eryptosis.

\section{Results and Discussion}

The present study explored whether celecoxib triggers suicidal erythrocyte death or eryptosis, which is characterized by cell shrinkage and cell membrane scrambling, both events stimulated by increase of cytosolic $\mathrm{Ca}^{2+}$ activity $\left(\left[\mathrm{Ca}^{2+}\right]_{\mathrm{i}}\right)$. In a first step, the effect of celecoxib on $\left[\mathrm{Ca}^{2+}\right]_{\mathrm{i}}$ was tested. To this end, human erythrocytes were loaded with Fluo3-AM and the Fluo3 fluorescence determined by flow cytometry. Prior to determination of Fluo3-fluorescence erythrocytes were incubated in Ringer solution without or with celecoxib $(5-15 \mu \mathrm{M})$. As illustrated in Figure 1, a $48 \mathrm{~h}$ exposure of human erythrocytes to celecoxib resulted in an increase of Fluo3 fluorescence, an effect reaching statistical significance at $15 \mu \mathrm{M}$ celecoxib concentration. Thus, celecoxib increased cytosolic $\mathrm{Ca}^{2+}$ concentration.

An increase of $\left[\mathrm{Ca}^{2+}\right]_{i}$ has been shown to activate $\mathrm{Ca}^{2+}$-sensitive $\mathrm{K}^{+}$channels resulting in cell shrinkage due to $\mathrm{KCl}$ exit paralleled by osmotically obliged water. Cell volume was thus estimated from forward scatter determined in flow cytometry. As illustrated in Figure 2, a $48 \mathrm{~h}$ exposure to celecoxib led to a decrease of forward scatter, an effect reaching statistical significance at $15 \mu \mathrm{M}$ celecoxib. Accordingly, celecoxib treatment was followed by erythrocyte shrinkage. 
Figure 1. Effect of celecoxib on erythrocyte cytosolic $\mathrm{Ca}^{2+}$ concentration (A) Original histogram of Fluo3 fluorescence in erythrocytes following exposure for $48 \mathrm{~h}$ to Ringer solution (grey area) and with (black line) presence of $15 \mu \mathrm{M}$ celecoxib; (B) Arithmetic means \pm SEM $(n=10)$ of the Fluo3 fluorescence (arbitrary units) in erythrocytes exposed for $48 \mathrm{~h}$ to Ringer solution without (white bar) or with (black bars) celecoxib $(5-15 \mu \mathrm{M})$. $* *(p<0.01)$ indicates significant difference from the absence of celecoxib (ANOVA).

A

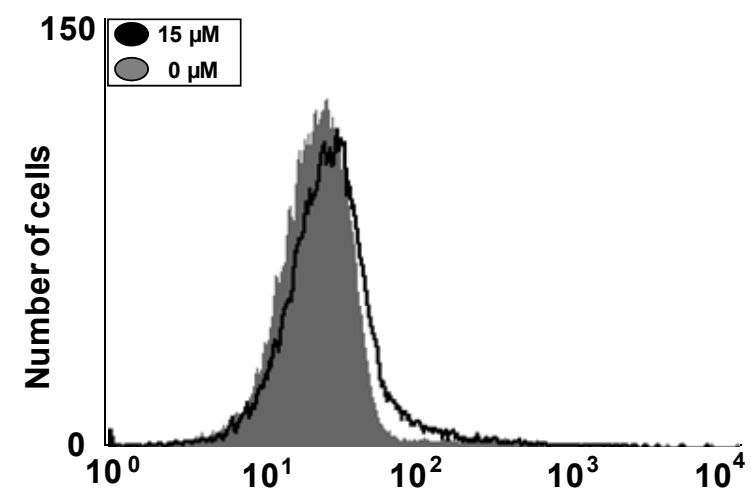

Fluo 3 Fluorescence (rel.units)
B

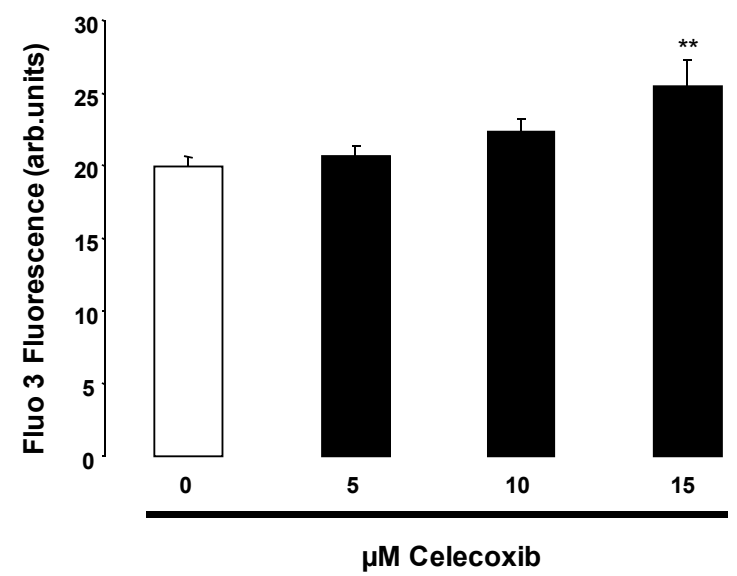

Figure 2. Effect of celecoxib on erythrocyte forward scatter. (A) Original histogram of forward scatter of erythrocytes following exposure for $48 \mathrm{~h}$ to Ringer solution without (grey area) and with (black line) presence of $15 \mu \mathrm{M}$ celecoxib; (B) Arithmetic means \pm SEM $(n=10)$ of the normalized erythrocyte forward scatter (FSC) following incubation for $48 \mathrm{~h}$ to Ringer solution without (white bar) or with (black bars) celecoxib $(5-15 \mu \mathrm{M}) . *(p<0.05)$ indicates significant difference from the absence of celecoxib (ANOVA).

A

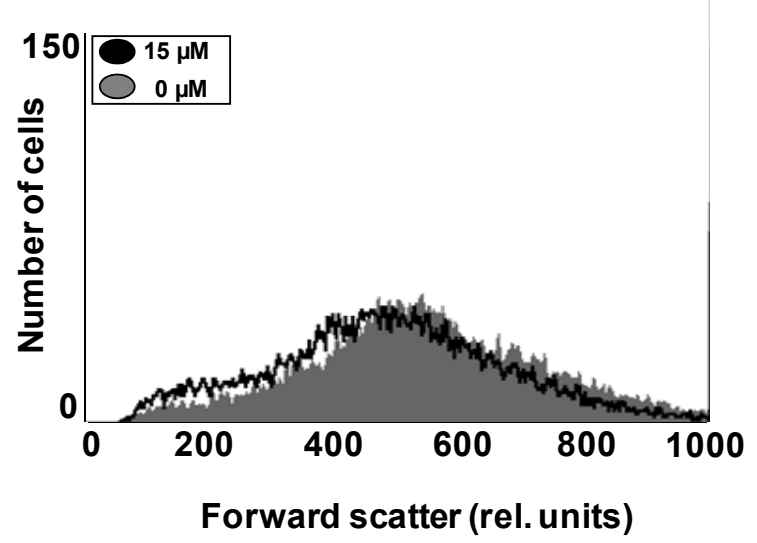

\section{B}

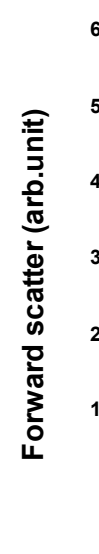

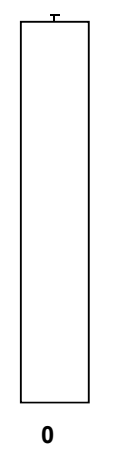

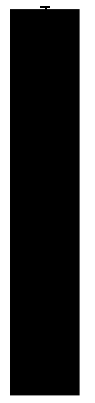

5

$\mu \mathrm{M}$ Celecoxib

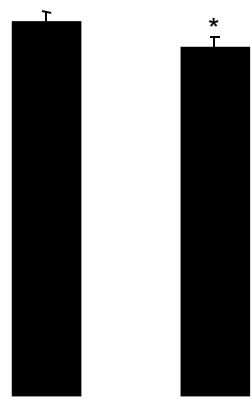

$10 \quad 15$

Increased $\left[\mathrm{Ca}^{2+}\right]_{\mathrm{i}}$ has further been shown to stimulate cell membrane phospholipid scrambling with phosphatidylserine exposure at the erythrocyte surface. To identify phosphatidylserine exposing 
erythrocytes annexin-V-binding was determined in flow cytometry. As shown in Figure 3, a $48 \mathrm{~h}$ exposure to celecoxib increased the percentage of annexin-V-binding erythrocytes, an effect reaching statistical significance at $10 \mu \mathrm{M}$ celecoxib. Accordingly, celecoxib triggered erythrocyte cell membrane scrambling with phosphatidylserine exposure at the cell surface.

Figure 3. Effect of celecoxib on phosphatidylserine exposure and hemolysis. (A) Original histogram of annexin-V-binding of erythrocytes following exposure for $48 \mathrm{~h}$ to Ringer solution without (grey area) and with (black line) presence of $15 \mu \mathrm{M}$ celecoxib; (B) Arithmetic means \pm SEM of erythrocyte annexin-V-binding $(n=10)$ following incubation for $48 \mathrm{~h}$ to Ringer solution without (white bar) or with (black bars) presence of celecoxib $(5-15 \mu \mathrm{M}) . * *(p<0.01), * * *(p<0.001)$ indicate significant difference from the absence of celecoxib (ANOVA).

A

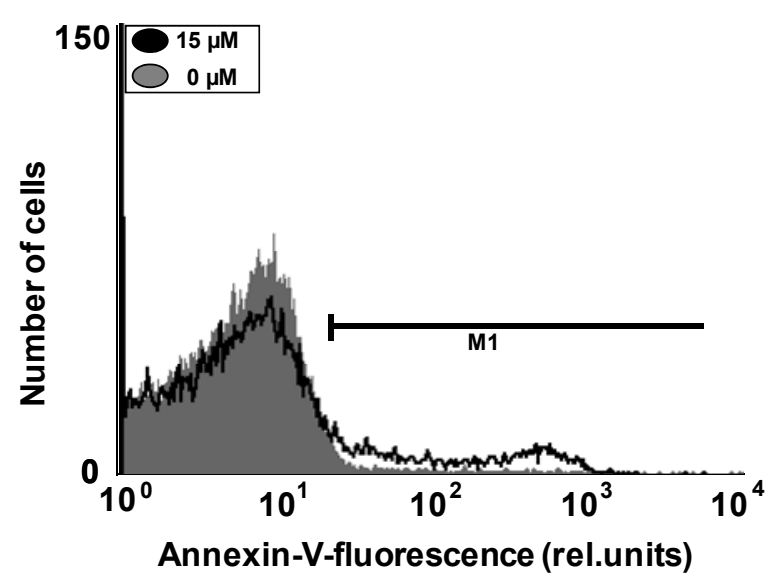

B

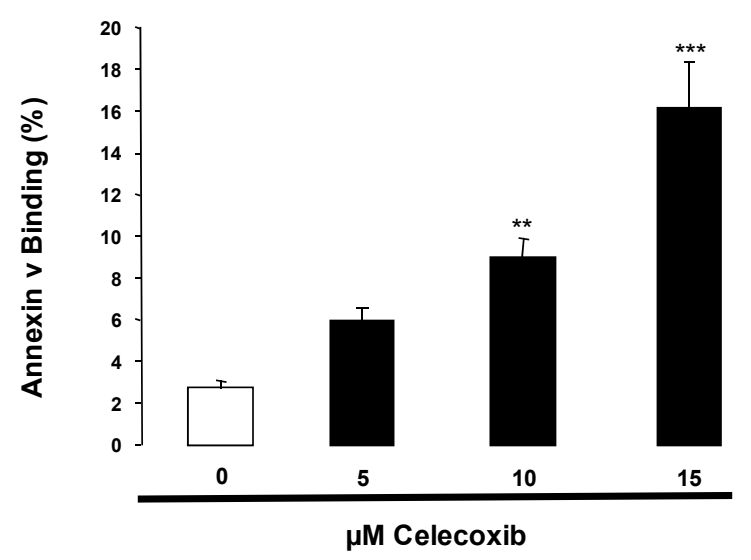

To explore whether celecoxib exposure triggers hemolysis, the percentage of hemolysed erythrocytes was estimated from hemoglobin concentration in the supernatant. As a result, the percentage of hemolysed erythrocytes approached $0.7 \% \pm 0.2 \%, 2.5 \% \pm 1.5 \%, 4.4 \% \pm 1.8 \%$ and $9.6 \% \pm 3.2 \%$ following exposure of erythrocytes for $48 \mathrm{~h}$ to $0,5,10$, and $15 \mu \mathrm{M}$ celecoxib $(n=4)$.

In order to test, whether the celecoxib induced increase of $\left[\mathrm{Ca}^{2+}\right]_{\mathrm{i}}$ indeed contributed to or even accounted for the stimulation of celecoxib induced cell membrane scrambling, erythrocytes were exposed to $15 \mu \mathrm{M}$ celecoxib for $48 \mathrm{~h}$ in the presence and in the nominal absence of extracellular $\mathrm{Ca}^{2+}$. As illustrated in Figure 4, the effect of celecoxib on annexin-V-binding was significatly blunted in the nominal absence of $\mathrm{Ca}^{2+}$. However, even in the nominal absence of extracellular $\mathrm{Ca}^{2+}$, celecoxib still significantly increased the percentage of annexin $\mathrm{V}$ binding erythrocytes. Thus, the effect of celecoxib was mainly but not exclusively due to $\mathrm{Ca}^{2+}$ entry.

The present study discloses a novel effect of celecoxib, i.e., the stimulation of eryptosis, the suicidal death of erythrocytes. Treatment of human erythrocytes with celecoxib is followed by erythrocyte shrinkage and erythrocyte cell membrane scrambling, the hallmarks of eryptosis. The celecoxib concentrations required (10-15 $\mu \mathrm{M})$ are similar to those (14.4-29.3) encountered in vivo [65]. 
Figure 4. Effect of $\mathrm{Ca}^{2+}$ withdrawal on celecoxib-induced annexin-V-binding. Arithmetic means $\pm \operatorname{SEM}(n=6)$ of the percentage of annexin-V-binding erythrocytes after a $48 \mathrm{~h}$ treatment with Ringer solution without (white bar) or with (black bars) $15 \mu \mathrm{M}$ celecoxib in the presence (left bars, Plus Calcium) and absence (right bars, Minus Calcium) of calcium. $*(p<0.05), * * *(p<0.001)$, indicate significant difference from the respective values in absence of celecoxib, \# $(p<0.05)$ indicates significant difference from the respective value in the presence of $\mathrm{Ca}^{2+}(\mathrm{ANOVA})$.

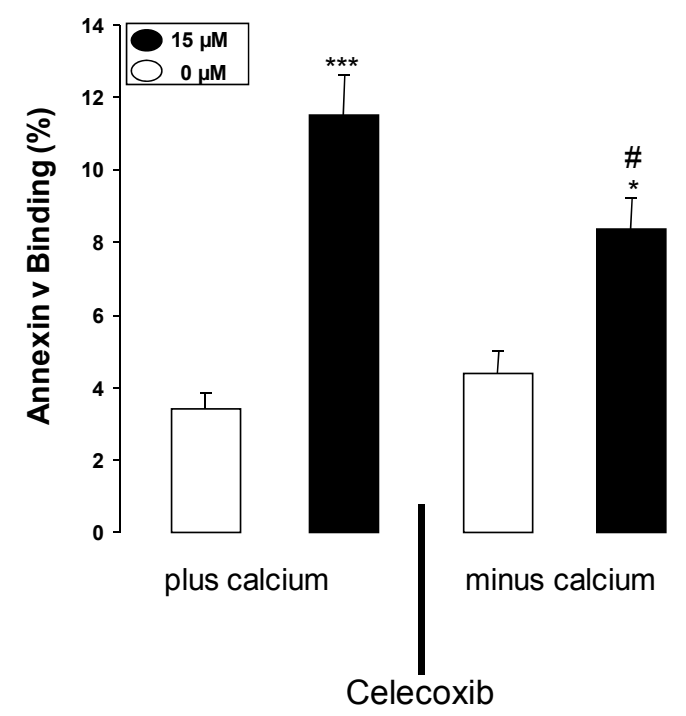

The effect of celecoxib was paralleled by an increase of cytosolic $\mathrm{Ca}^{2+}$ activity, an effect paralleling a similar effect in nucelated cells [6]. The effect on annexin V binding was significantly blunted in the absence of extracellular $\mathrm{Ca}^{2+}$. Thus, the effect of celecoxib on cell membrane scrambling is at least in part due to stimulation of $\mathrm{Ca}^{2+}$ entry. Celecoxib presumably activates the $\mathrm{Ca}^{2+}$ permeable non-selective cation channels in erythrocytes. The molecular identity of those channels is incompletely defined but the channels involve the transient receptor potential channel TRPC6 [8]. Celecoxib presumably activates those channels possibly by inducing oxidative stress, which could be triggered by celecoxib [66,67] and is known to activate unspecific $\mathrm{Ca}^{2+}$ permeable cation channels in erythrocytes [10].

$\mathrm{Ca}^{2+}$ entry through the unspecific $\mathrm{Ca}^{2+}$ permeable cation channels further contributes to or even accounts for the celecoxib induced erythrocyte shrinkage. Erythrocytes express $\mathrm{Ca}^{2+}$ sensitive $\mathrm{K}^{+}$ channels [11,68], which are activated by increase of cytosolic $\mathrm{Ca}^{2+}$ activity. Activation of those channels results in cell shrinkage due to $\mathrm{K}^{+}$exit, cell membrane hyperpolarisation, $\mathrm{Cl}^{-}$exit and thus cellular loss of $\mathrm{KCl}$ with osmotically obliged water [12].

The stimulating effect of COX-2 inhibitor celecoxib is in seeming contrast to the effect of unselective COX inhibitors observed earlier. Osmotic cell shrinkage has been shown to trigger the release of $\mathrm{PGE}_{2}$, which in turn activates the unspecific cation channels and thus triggers $\mathrm{Ca}^{2+}$ entry and suicidal erythrocyte death [69]. In the presence of unspecific $\mathrm{COX}$ inhibitors $\mathrm{Ca}^{2+}$ entry and suicidal erythrocyte death following hyperosmotic shock were significantly blunted. Presumably, the $\mathrm{Ca}^{2+}$ entry and suicidal erythrocyte death observed following exposure of erythrocytes to celecoxib is not due to inhibition of $\mathrm{PGE}_{2}$ formation but due to an unrelated side effect of the drug. 
Phosphatidylserine exposing erythrocytes adhere to endothelial CXCL16/SR-PSO of the vascular wall [70]. The adherence of the phosphatidylserine exposing erythrocytes to the vascular wall presumably interferes with blood flow [70-75]. Thus, eryptosis may be expected to impair microcirculation. Moreover, phosphatidylserine exposure of erythrocytes fosters blood clotting and may thus cause thrombosis [71,76,77], a side effect observed following celecoxib treatment [78].

Phosphatidylserine exposing erythrocytes are further rapidly cleared from circulating blood [7]. If the accelerated loss of erythrocytes cannot be outweighed by compensating increase of erythrocyte formation, the stimulation of eryptosis may lead to anemia [7], again a known side effect of celecoxib [79].

\section{Methods}

\subsection{Erythrocytes, Solutions and Chemicals}

Leukocyte-depleted erythrocytes were kindly provided by the blood bank of the University of Tübingen. The study is approved by the ethics committee of the University of Tübingen (184/2003 V). Erythrocytes were incubated in vitro at a hematocrit of $0.4 \%$ in Ringer solution containing (in $\mathrm{mM}$ ) $125 \mathrm{NaCl}, 5 \mathrm{KCl}, 1 \mathrm{MgSO}_{4}, 32 \mathrm{~N}$-2-hydroxyethylpiperazine- $N$-2-ethanesulfonic acid (HEPES), 5 glucose, $1 \mathrm{CaCl}_{2} ; \mathrm{pH} 7.4$ at $37^{\circ} \mathrm{C}$ for $48 \mathrm{~h}$. Where indicated, erythrocytes were exposed to celecoxib (Sigma, Freiburg, Germany) at the indicated concentrations. In $\mathrm{Ca}^{2+}$-free Ringer solution, $1 \mathrm{mM} \mathrm{CaCl}_{2}$ was substituted by $1 \mathrm{mM}$ glycol-bis(2-aminoethylether)- $N, N, N^{\prime}, N^{\prime}$-tetraacetic acid (EGTA).

\subsection{FACS Analysis of Annexin-V-Binding and Forward Scatter}

After incubation under the respective experimental condition, $50 \mu \mathrm{L}$ cell suspension was washed in Ringer solution containing $5 \mathrm{mM} \mathrm{CaCl}_{2}$ and then stained with Annexin-V-FITC (1:200 dilution; ImmunoTools, Friesoythe, Germany) in this solution at $37{ }^{\circ} \mathrm{C}$ for $20 \mathrm{~min}$ under protection from light. In the following, the forward scatter (FSC) of the cells was determined, and annexin-V fluorescence intensity was measured with an excitation wavelength of $488 \mathrm{~nm}$ and an emission wavelength of $530 \mathrm{~nm}$ on a FACS Calibur (BD, Heidelberg, Germany).

\subsection{Measurement of Intracellular $\mathrm{Ca}^{2+}$}

After incubation erythrocytes were washed in Ringer solution and then loaded with Fluo-3/AM (Biotium, Hayward, CA, USA) in Ringer solution containing $5 \mathrm{mM} \mathrm{CaCl}_{2}$ and $2 \mu \mathrm{M}$ Fluo-3/AM. The cells were incubated at $37^{\circ} \mathrm{C}$ for $30 \mathrm{~min}$ and washed twice in Ringer solution containing $5 \mathrm{mM} \mathrm{CaCl}_{2}$. The Fluo-3/AM-loaded erythrocytes were resuspended in $200 \mu \mathrm{L}$ Ringer. Then, $\mathrm{Ca}^{2+}$-dependent fluorescence intensity was measured with an excitation wavelength of $488 \mathrm{~nm}$ and an emission wavelength of $530 \mathrm{~nm}$ on a FACS Calibur (BD, Heidelberg, Germany).

\subsection{Measurement of Hemolysis}

For the determination of hemolysis the samples were centrifuged ( 3 min at $400 g$, room temperature) after incubation, and the supernatants were harvested. As a measure of hemolysis, the hemoglobin 
$\mathrm{Hb}$ concentration of the supernatant was determined photometrically at $405 \mathrm{~nm}$. The absorption of the supernatant of erythrocytes lysed in distilled water was defined as $100 \%$ hemolysis.

\subsection{Statistics}

Data are expressed as arithmetic means \pm SEM. As indicated in the figure legends, statistical analysis was made using ANOVA with Tukey's test as post-test and $t$ test as appropriate. $\mathrm{n}$ denotes the number of different erythrocyte specimens studied. Since different erythrocyte specimens used in distinct experiments are differently susceptible to triggers of eryptosis, the same erythrocyte specimens have been used for control and experimental conditions.

\section{Conclusions}

Celecoxib triggers cell shrinkage and cell membrane scrambling of human erythrocytes, an effect at least partially due to stimulation of $\mathrm{Ca}^{2+}$ entry. Celecoxib is thus able to trigger suicidal death of erythrocytes, i.e., cells devoid of mitochondria and nuclei.

\section{Acknowledgements}

The authors acknowledge the meticulous preparation of the manuscript by Tanja Loch. The study was supported by the Deutsche Forschungsgemeinschaft and the Open Access Publishing Fund of Tuebingen University.

\section{Conflicts of Interest}

The authors declare no conflict of interest.

\section{References}

1. Jendrossek, V. Targeting apoptosis pathways by celecoxib in cancer. Cancer Lett. 2013, 332, 313-324.

2. Kismet, K.; Akay, M.T.; Abbasoglu, O.; Ercan, A. Celecoxib: A potent cyclooxygenase-2 inhibitor in cancer prevention. Cancer Detect. Prev. 2004, 28, 127-142.

3. Schonthal, A.H. Antitumor properties of dimethyl-celecoxib, a derivative of celecoxib that does not inhibit cyclooxygenase-2: Implications for glioma therapy. Neurosurg. Focus 2006, 20 , E21.

4. Winfield, L.L.; Payton-Stewart, F. Celecoxib and bcl-2: Emerging possibilities for anticancer drug design. Future Med. Chem. 2012, 4, 361-383.

5. Blanke, C.D. Celecoxib with chemotherapy in colorectal cancer. Oncology 2002, 16, 17-21.

6. Wang, J.L.; Lin, K.L.; Chou, C.T.; Kuo, C.C.; Cheng, J.S.; Hsu, S.S.; Chang, H.T.; Tsai, J.Y.; Liao, W.C.; Lu, Y.C.; et al. Effect of celecoxib on $\mathrm{Ca}(2+)$ handling and viability in human prostate cancer cells (pc3). Drug Chem. Toxicol. 2012, 35, 456-462.

7. Lang, F.; Gulbins, E.; Lerche, H.; Huber, S.M.; Kempe, D.S.; Foller, M. Eryptosis, a window to systemic disease. Cell. Physiol. Biochem. 2008, 22, 373-380. 
8. Foller, M.; Kasinathan, R.S.; Koka, S.; Lang, C.; Shumilina, E.; Birnbaumer, L.; Lang, F.; Huber, S.M. Trpc6 contributes to the $\mathrm{Ca}(2+)$ leak of human erythrocytes. Cell. Physiol. Biochem. 2008, 21, 183-192.

9. Foller, M.; Sopjani, M.; Koka, S.; Gu, S.; Mahmud, H.; Wang, K.; Floride, E.; Schleicher, E.; Schulz, E.; Munzel, T.; et al. Regulation of erythrocyte survival by amp-activated protein kinase. FASEB J. 2009, 23, 1072-1080.

10. Brand, V.B.; Sandu, C.D.; Duranton, C.; Tanneur, V.; Lang, K.S.; Huber, S.M.; Lang, F. Dependence of plasmodium falciparum in vitro growth on the cation permeability of the human host erythrocyte. Cell. Physiol. Biochem. 2003, 13, 347-356.

11. Brugnara, C.; de Franceschi, L.; Alper, S.L. Inhibition of $\mathrm{Ca}(2+)$-dependent $\mathrm{K}^{+}$transport and cell dehydration in sickle erythrocytes by clotrimazole and other imidazole derivatives. J. Clin. Invest. 1993, 92, 520-526.

12. Lang, P.A.; Kaiser, S.; Myssina, S.; Wieder, T.; Lang, F.; Huber, S.M. Role of $\mathrm{Ca}^{2+}$-activated K channels in human erythrocyte apoptosis. Am. J. Physiol. Cell. Physiol. 2003, 285, C1553-C1560.

13. Berg, C.P.; Engels, I.H.; Rothbart, A.; Lauber, K.; Renz, A.; Schlosser, S.F.; Schulze-Osthoff, K.; Wesselborg, S. Human mature red blood cells express caspase-3 and caspase-8, but are devoid of mitochondrial regulators of apoptosis. Cell Death Differ. 2001, 8, 1197-1206.

14. Lang, F.; Gulbins, E.; Lang, P.A.; Zappulla, D.; Foller, M. Ceramide in suicidal death of erythrocytes. Cell. Physiol. Biochem. 2010, 26, 21-28.

15. Klarl, B.A.; Lang, P.A.; Kempe, D.S.; Niemoeller, O.M.; Akel, A.; Sobiesiak, M.; Eisele, K.; Podolski, M.; Huber, S.M.; Wieder, T.; et al. Protein kinase c mediates erythrocyte "programmed cell death" following glucose depletion. Am. J. Physiol. Cell. Physiol. 2006, 290, C244-C253.

16. Bhavsar, S.K.; Bobbala, D.; Xuan, N.T.; Foller, M.; Lang, F. Stimulation of suicidal erythrocyte death by alpha-lipoic acid. Cell. Physiol. Biochem. 2010, 26, 859-868.

17. Foller, M.; Huber, S.M.; Lang, F. Erythrocyte programmed cell death. IUBMB Life 2008, 60, 661-668.

18. Foller, M.; Mahmud, H.; Gu, S.; Wang, K.; Floride, E.; Kucherenko, Y.; Luik, S.; Laufer, S.; Lang, F. Participation of leukotriene $\mathrm{c}(4)$ in the regulation of suicidal erythrocyte death. J. Physiol. Pharmacol. 2009, 60, 135-143.

19. Lau, I.P.; Chen, H.; Wang, J.; Ong, H.C.; Leung, K.C.; Ho, H.P.; Kong, S.K. In vitro effect of ctab- and peg-coated gold nanorods on the induction of eryptosis/erythroptosis in human erythrocytes. Nanotoxicology 2011, in press, doi:10.3109/17435390.2011.625132.

20. Maellaro, E.; Leoncini, S.; Moretti, D.; del Bello, B.; Tanganelli, I.; de Felice, C.; Ciccoli, L. Erythrocyte caspase- 3 activation and oxidative imbalance in erythrocytes and in plasma of type 2 diabetic patients. Acta Diabetol. 2011, in press, doi:10.1007/s00592-011-0274-0.

21. Foller, M.; Feil, S.; Ghoreschi, K.; Koka, S.; Gerling, A.; Thunemann, M.; Hofmann, F.; Schuler, B.; Vogel, J.; Pichler, B.; et al. Anemia and splenomegaly in cgki-deficient mice. Proc. Natl. Acad. Sci. USA 2008, 105, 6771-6776.

22. Bhavsar, S.K.; Gu, S.; Bobbala, D.; Lang, F. Janus kinase 3 is expressed in erythrocytes, phosphorylated upon energy depletion and involved in the regulation of suicidal erythrocyte death. Cell. Physiol. Biochem. 2011, 27, 547-556. 
23. Kucherenko, Y.V.; Huber, S.M.; Nielsen, S.; Lang, F. Decreased redox-sensitive erythrocyte cation channel activity in aquaporin 9-deficient mice. J. Membr. Biol. 2012, 245, 797-805.

24. Zelenak, C.; Foller, M.; Velic, A.; Krug, K.; Qadri, S.M.; Viollet, B.; Lang, F.; Macek, B. Proteome analysis of erythrocytes lacking amp-activated protein kinase reveals a role of pak2 kinase in eryptosis. J. Proteome Res. 2011, 10, 1690-1697.

25. Gatidis, S.; Zelenak, C.; Fajol, A.; Lang, E.; Jilani, K.; Michael, D.; Qadri, S.M.; Lang, F. P38 mapk activation and function following osmotic shock of erythrocytes. Cell. Physiol. Biochem. 2011, 28, 1279-1286.

26. Lupescu, A.; Shaik, N.; Jilani, K.; Zelenak, C.; Lang, E.; Pasham, V.; Zbidah, M.; Plate, A.; Bitzer, M.; Foller, M.; et al. Enhanced erythrocyte membrane exposure of phosphatidylserine following sorafenib treatment: An in vivo and in vitro study. Cell. Physiol. Biochem. 2012, 30, 876-888.

27. Shaik, N.; Lupescu, A.; Lang, F. Sunitinib-sensitive suicidal erythrocyte death. Cell. Physiol. Biochem. 2012, 30, 512-522.

28. Jilani, K.; Enkel, S.; Bissinger, R.; Almilaji, A.; Abed, M.; Lang, F. Fluoxetine induced suicidal erythrocyte death. Toxins 2013, 5, 1230-1243.

29. Jilani, K.; Lang, F. Carmustine-induced phosphatidylserine translocation in the erythrocyte membrane. Toxins 2013, 5, 703-716.

30. Bottger, E.; Multhoff, G.; Kun, J.F.; Esen, M. Plasmodium falciparum-infected erythrocytes induce granzyme b by nk cells through expression of host-hsp70. PLoS One 2012, 7, e33774.

31. Felder, K.M.; Hoelzle, K.; Ritzmann, M.; Kilchling, T.; Schiele, D.; Heinritzi, K.; Groebel, K.; Hoelzle, L.E. Hemotrophic mycoplasmas induce programmed cell death in red blood cells. Cell. Physiol. Biochem. 2011, 27, 557-564.

32. Firat, U.; Kaya, S.; Cim, A.; Buyukbayram, H.; Gokalp, O.; Dal, M.S.; Tamer, M.N. Increased caspase-3 immunoreactivity of erythrocytes in stz diabetic rats. Exp. Diabetes Res. 2012, 2012, 316384.

33. Ganesan, S.; Chaurasiya, N.D.; Sahu, R.; Walker, L.A.; Tekwani, B.L. Understanding the mechanisms for metabolism-linked hemolytic toxicity of primaquine against glucose 6-phosphate dehydrogenase deficient human erythrocytes: Evaluation of eryptotic pathway. Toxicology 2012, 294, 54-60.

34. Gao, M.; Cheung, K.L.; Lau, I.P.; Yu, W.S.; Fung, K.P.; Yu, B.; Loo, J.F.; Kong, S.K. Polyphyllin $\mathrm{d}$ induces apoptosis in human erythrocytes through $\mathrm{Ca}(2)(+)$ rise and membrane permeabilization. Arch. Toxicol. 2012, 86, 741-752.

35. Ghashghaeinia, M.; Toulany, M.; Saki, M.; Bobbala, D.; Fehrenbacher, B.; Rupec, R.; Rodemann, H.P.; Ghoreschi, K.; Rocken, M.; Schaller, M.; et al. The nfkb pathway inhibitors bay 11-7082 and parthenolide induce programmed cell death in anucleated erythrocytes. Cell. Physiol. Biochem. 2011, 27, 45-54.

36. Jilani, K.; Lupescu, A.; Zbidah, M.; Abed, M.; Shaik, N.; Lang, F. Enhanced apoptotic death of erythrocytes induced by the mycotoxin ochratoxin a. Kidney Blood Press. Res. 2012, 36, 107-118.

37. Kucherenko, Y.V.; Lang, F. Inhibitory effect of furosemide on non-selective voltage-independent cation channels in human erythrocytes. Cell. Physiol. Biochem. 2012, 30, 863-875. 
38. Lang, E.; Jilani, K.; Zelenak, C.; Pasham, V.; Bobbala, D.; Qadri, S.M.; Lang, F. Stimulation of suicidal erythrocyte death by benzethonium. Cell. Physiol. Biochem. 2011, 28, 347-354.

39. Lang, E.; Qadri, S.M.; Jilani, K.; Zelenak, C.; Lupescu, A.; Schleicher, E.; Lang, F. Carbon monoxide-sensitive apoptotic death of erythrocytes. Basic Clin. Pharmacol. Toxicol. 2012, 111, 348-355.

40. Lang, F.; Qadri, S.M. Mechanisms and significance of eryptosis, the suicidal death of erythrocytes. Blood Purif. 2012, 33, 125-130.

41. Polak-Jonkisz, D.; Purzyc, L. Ca(2+) influx versus efflux during eryptosis in uremic erythrocytes. Blood Purif. 2012, 34, 209-210.

42. Qadri, S.M.; Kucherenko, Y.; Zelenak, C.; Jilani, K.; Lang, E.; Lang, F. Dicoumarol activates $\mathrm{Ca}^{2+}$-permeable cation channels triggering erythrocyte cell membrane scrambling. Cell. Physiol. Biochem. 2011, 28, 857-864.

43. Qadri, S.M.; Bauer, J.; Zelenak, C.; Mahmud, H.; Kucherenko, Y.; Lee, S.H.; Ferlinz, K.; Lang, F. Sphingosine but not sphingosine-1-phosphate stimulates suicidal erythrocyte death. Cell. Physiol. Biochem. 2011, 28, 339-346.

44. Qian, E.W.; Ge, D.T.; Kong, S.K. Salidroside protects human erythrocytes against hydrogen peroxide-induced apoptosis. J. Nat. Prod. 2012, 75, 531-537.

45. Shaik, N.; Zbidah, M.; Lang, F. Inhibition of $\mathrm{Ca}(2+)$ entry and suicidal erythrocyte death by naringin. Cell. Physiol. Biochem. 2012, 30, 678-686.

46. Weiss, E.; Cytlak, U.M.; Rees, D.C.; Osei, A.; Gibson, J.S. Deoxygenation-induced and Ca(2+) dependent phosphatidylserine externalisation in red blood cells from normal individuals and sickle cell patients. Cell Calcium 2012, 51, 51-56.

47. Zelenak, C.; Pasham, V.; Jilani, K.; Tripodi, P.M.; Rosaclerio, L.; Pathare, G.; Lupescu, A.; Faggio, C.; Qadri, S.M.; Lang, F. Tanshinone iia stimulates erythrocyte phosphatidylserine exposure. Cell. Physiol. Biochem. 2012, 30, 282-294.

48. Lang, E.; Qadri, S.M.; Lang, F. Killing me softly-Suicidal erythrocyte death. Int. J. Biochem. Cell. Biol. 2012, 44, 1236-1243.

49. Vota, D.M.; Maltaneri, R.E.; Wenker, S.D.; Nesse, A.B.; Vittori, D.C. Differential erythropoietin action upon cells induced to eryptosis by different agents. Cell. Biochem. Biophys. 2013, 65, $145-157$.

50. Vota, D.M.; Crisp, R.L.; Nesse, A.B.; Vittori, D.C. Oxidative stress due to aluminum exposure induces eryptosis which is prevented by erythropoietin. J. Cell. Biochem. 2012, 113, 1581-1589.

51. Zappulla, D. Environmental stress, erythrocyte dysfunctions, inflammation, and the metabolic syndrome: Adaptations to co2 increases? J. Cardiometab. Syndr. 2008, 3, 30-34.

52. Calderon-Salinas, J.V.; Munoz-Reyes, E.G.; Guerrero-Romero, J.F.; Rodriguez-Moran, M.; Bracho-Riquelme, R.L.; Carrera-Gracia, M.A.; Quintanar-Escorza, M.A. Eryptosis and oxidative damage in type 2 diabetic mellitus patients with chronic kidney disease. Mol. Cell. Biochem. 2011, 357, 171-179.

53. Nicolay, J.P.; Schneider, J.; Niemoeller, O.M.; Artunc, F.; Portero-Otin, M.; Haik, G., Jr.; Thornalley, P.J.; Schleicher, E.; Wieder, T.; Lang, F. Stimulation of suicidal erythrocyte death by methylglyoxal. Cell. Physiol. Biochem. 2006, 18, 223-232. 
54. Myssina, S.; Huber, S.M.; Birka, C.; Lang, P.A.; Lang, K.S.; Friedrich, B.; Risler, T.; Wieder, T.; Lang, F. Inhibition of erythrocyte cation channels by erythropoietin. J. Am. Soc. Nephrol. 2003, 14, 2750-2757.

55. Lang, P.A.; Beringer, O.; Nicolay, J.P.; Amon, O.; Kempe, D.S.; Hermle, T.; Attanasio, P.; Akel, A.; Schafer, R.; Friedrich, B.; et al. Suicidal death of erythrocytes in recurrent hemolytic uremic syndrome. J. Mol. Med. 2006, 84, 378-388.

56. Kempe, D.S.; Akel, A.; Lang, P.A.; Hermle, T.; Biswas, R.; Muresanu, J.; Friedrich, B.; Dreischer, P.; Wolz, C.; Schumacher, U.; et al. Suicidal erythrocyte death in sepsis. J. Mol. Med. 2007, 85, 273-281.

57. Lang, P.A.; Kasinathan, R.S.; Brand, V.B.; Duranton, C.; Lang, C.; Koka, S.; Shumilina, E.; Kempe, D.S.; Tanneur, V.; Akel, A.; et al. Accelerated clearance of plasmodium-infected erythrocytes in sickle cell trait and annexin-a7 deficiency. Cell. Physiol. Biochem. 2009, 24, 415-428.

58. Siraskar, B.; Ballal, A.; Bobbala, D.; Foller, M.; Lang, F. Effect of amphotericin b on parasitemia and survival of plasmodium berghei-infected mice. Cell. Physiol. Biochem. 2010, 26, 347-354.

59. Bobbala, D.; Alesutan, I.; Foller, M.; Huber, S.M.; Lang, F. Effect of anandamide in plasmodium berghei-infected mice. Cell. Physiol. Biochem. 2010, 26, 355-362.

60. Foller, M.; Bobbala, D.; Koka, S.; Huber, S.M.; Gulbins, E.; Lang, F. Suicide for survival—Death of infected erythrocytes as a host mechanism to survive malaria. Cell. Physiol. Biochem. 2009, 24, 133-140.

61. Koka, S.; Bobbala, D.; Lang, C.; Boini, K.M.; Huber, S.M.; Lang, F. Influence of paclitaxel on parasitemia and survival of plasmodium berghei infected mice. Cell. Physiol. Biochem. 2009, 23, 191-198.

62. Lang, P.A.; Schenck, M.; Nicolay, J.P.; Becker, J.U.; Kempe, D.S.; Lupescu, A.; Koka, S.; Eisele, K.; Klarl, B.A.; Rubben, H.; et al. Liver cell death and anemia in wilson disease involve acid sphingomyelinase and ceramide. Nat. Med. 2007, 13, 164-170.

63. Kempe, D.S.; Lang, P.A.; Duranton, C.; Akel, A.; Lang, K.S.; Huber, S.M.; Wieder, T.; Lang, F. Enhanced programmed cell death of iron-deficient erythrocytes. FASEB J. 2006, 20, 368-370.

64. Birka, C.; Lang, P.A.; Kempe, D.S.; Hoefling, L.; Tanneur, V.; Duranton, C.; Nammi, S.; Henke, G.; Myssina, S.; Krikov, M.; et al. Enhanced susceptibility to erythrocyte "apoptosis" following phosphate depletion. Pflugers Arch. 2004, 448, 471-477.

65. Niederberger, E.; Tegeder, I.; Vetter, G.; Schmidtko, A.; Schmidt, H.; Euchenhofer, C.; Brautigam, L.; Grosch, S.; Geisslinger, G. Celecoxib loses its anti-inflammatory efficacy at high doses through activation of nf-kappab. FASEB J. 2001, 15, 1622-1624.

66. Kim, C.H.; Chung, C.W.; Lee, H.M.; Kim, D.H.; Kwak, T.W.; Jeong, Y.I.; Kang, D.H. Synergistic effects of 5-aminolevulinic acid based photodynamic therapy and celecoxib via oxidative stress in human cholangiocarcinoma cells. Int. J. Nanomed. 2013, 8, 2173-2185.

67. Lampiasi, N.; Azzolina, A.; Umezawa, K.; Montalto, G.; McCubrey, J.A.; Cervello, M. The novel nf-kappab inhibitor dhmeq synergizes with celecoxib to exert antitumor effects on human liver cancer cells by a ros-dependent mechanism. Cancer Lett. 2012, 322, 35-44.

68. Bookchin, R.M.; Ortiz, O.E.; Lew, V.L. Activation of calcium-dependent potassium channels in deoxygenated sickled red cells. Prog. Clin. Biol. Res. 1987, 240, 193-200. 
69. Lang, P.A.; Kempe, D.S.; Myssina, S.; Tanneur, V.; Birka, C.; Laufer, S.; Lang, F.; Wieder, T.; Huber, S.M. Pge(2) in the regulation of programmed erythrocyte death. Cell Death Differ. 2005, 12, 415-428.

70. Borst, O.; Abed, M.; Alesutan, I.; Towhid, S.T.; Qadri, S.M.; Foller, M.; Gawaz, M.; Lang, F. Dynamic adhesion of eryptotic erythrocytes to endothelial cells via cxcl16/sr-psox. Am. J. Physiol. Cell. Physiol. 2012, 302, C644-C651.

71. Andrews, D.A.; Low, P.S. Role of red blood cells in thrombosis. Curr. Opin. Hematol. 1999, 6, 76-82.

72. Closse, C.; Dachary-Prigent, J.; Boisseau, M.R. Phosphatidylserine-related adhesion of human erythrocytes to vascular endothelium. Br. J. Haematol. 1999, 107, 300-302.

73. Gallagher, P.G.; Chang, S.H.; Rettig, M.P.; Neely, J.E.; Hillery, C.A.; Smith, B.D.; Low, P.S. Altered erythrocyte endothelial adherence and membrane phospholipid asymmetry in hereditary hydrocytosis. Blood 2003, 101, 4625-4627.

74. Pandolfi, A.; di Pietro, N.; Sirolli, V.; Giardinelli, A.; di Silvestre, S.; Amoroso, L.; di Tomo, P.; Capani, F.; Consoli, A.; Bonomini, M. Mechanisms of uremic erythrocyte-induced adhesion of human monocytes to cultured endothelial cells. J. Cell. Physiol. 2007, 213, 699-709.

75. Wood, B.L.; Gibson, D.F.; Tait, J.F. Increased erythrocyte phosphatidylserine exposure in sickle cell disease: Flow-cytometric measurement and clinical associations. Blood 1996, 88, 1873-1880.

76. Chung, S.M.; Bae, O.N.; Lim, K.M.; Noh, J.Y.; Lee, M.Y.; Jung, Y.S.; Chung, J.H. Lysophosphatidic acid induces thrombogenic activity through phosphatidylserine exposure and procoagulant microvesicle generation in human erythrocytes. Arterioscler. Thromb. Vasc. Biol. 2007, 27, 414-421.

77. Zwaal, R.F.; Comfurius, P.; Bevers, E.M. Surface exposure of phosphatidylserine in pathological cells. Cell. Mol. Life Sci. 2005, 62, 971-988.

78. Chan, A.L. Celecoxib-induced deep-vein thrombosis. Ann. Pharmacother. 2005, 39, 1138.

79. Sands, G.; Shell, B.; Zhang, R. Adverse events in patients with blood loss: A pooled analysis of 51 clinical studies from the celecoxib clinical trial database. Open Rheumatol. J. 2012, 6, 44-49.

(C) 2013 by the authors; licensee MDPI, Basel, Switzerland. This article is an open access article distributed under the terms and conditions of the Creative Commons Attribution license (http://creativecommons.org/licenses/by/3.0/). 